\title{
Analysis of electricity consumption: a study in the wood products industry
}

\author{
Henry Quesada-Pineda • Jan Wiedenbeck • Brian Bond
}

Received: 1 April 2015 / Accepted: 8 December 2015 / Published online: 23 December 2015

(C) Springer Science+Business Media Dordrecht 2015

\begin{abstract}
This paper evaluates the effect of industry segment, year, and US region on electricity consumption per employee, per dollar sales, and per square foot of plant area for wood products industries. Data was extracted from the Industrial Assessment Center (IAC) database and imported into MS Excel. The extracted dataset was examined for outliers and abnormalities with outliers outside the quantile range 0.5-99.5 dropped from the analysis. A logarithmic transformation was applied to eliminate the skewness of the original data distributions. Correlation measurements indicated a moderate association between the response variables; therefore, a multivariate analysis of variance test was performed to measure the impact of the three factors: industry type, year, and region, simultaneously on all response variables. The results indicated some effect associated with all three factors on the three measures of electricity consumption. Subsequently, univariate ANOVA tests were conducted to determine the levels of the factors that were different. Most levels of industry type were associated with significantly different energy consumption, an expected result since some of the industries are more energy intensive than others. The industries in Standard Industry Code (SIC) 2493
\end{abstract}

H. Quesada-Pineda $(\bowtie) \cdot$ B. Bond

Virginia Tech, 1650 Research Tech Drive, Blacksburg, VA 24061, USA

e-mail: quesada@vt.edu

J. Wiedenbeck

U.S. Forest Service, 241 Mercer Spring Rd, Princeton, WV 24740 , USA (reconstituted wood products) are the groups with the highest electricity consumption with means of $38,096.28 \mathrm{kWh} / \mathrm{employee,} 0.86 \mathrm{kWh} / \mathrm{sales}$, and $154.14 \mathrm{kWh} /$ plant area while industries grouped in SIC 2451 (mobile homes) have the smallest consumption with means of $6811.01 \mathrm{kWh} / \mathrm{employee,} 0.05 \mathrm{kWh} /$ sales, and $9.45 \mathrm{kWh} /$ plant area. Interestingly, differences in regional consumption were found to be linked to the proportion of industry types by region. Data analysis also indicated differences in electricity consumption per employee for the factor year, but for the other response variables, no differences were found. These main results indicate that industries in the wood products sector have different electricity consumption rates depending on the type of manufacturing processes they use. Therefore, industries in this sector can use these comparisons and metrics to benchmark their electricity consumption as well to understand better how electricity costs might vary depending on the region they are located.

Keywords Energy usage · Wood products · Energy performance metrics

\section{Introduction}

The industrial sector of the USA (manufacturing, agriculture, construction, and mining) consumes over one third of the total energy consumed in the country (Energy Information Administration 2014a). Considering that energy is an important cost to industry, 
managers are constantly developing strategies to minimize its consumption. For hardwood manufacturing operations in the eastern USA, the average proportion of total operating costs in 2010 attributable to energy expenses was about $8 \%$ (Espinoza et al. 2011a). Efficient use of energy impacts not only manufacturing costs but also other dimensions of industries such as customer service and environmental aspects. A product that is manufactured using streamlined processes that minimize waste and consume less energy can be delivered with shortened lead times which leads to improved customer satisfaction (Quesada-Pineda and Buehlmann 2011). At the same time, reduced energy consumption leads to lowered emissions lessening the environmental impact.

Given the large variety of industries in the manufacturing sector, energy consumption varies dramatically. For example, the use of steam boilers required in most cases for lumber drying is one of the processes with the highest energy consumption in the forest products industry. According to Pellegrino et al. (2004), boiler fuels represents $60 \%$ and electricity $13 \%$ of the total energy use in the forest products industry (North American Industrial Classification System or NAICS subsectors NAICS 321 and 322). The wood products sector (NAICS subsectors 321 and $337^{1}$ ) consumed 510 million BTU of energy (all energy sources) in 2010, which represents $2.75 \%$ of all energy consumed by all manufacturing industry sectors in the USA (EIA $2014 b)$. In terms of electricity, the wood products sector consumed 20,283 million kWh (2.8\%) of all electricity consumed by the entire US manufacturing sector in 2010. Even though the consumption of electricity by the wood products sector might seem small in the overall US manufacturing picture, the economic, environmental, and social impacts of the industry in the USA and beyond has been considered of tremendous value by private, government, and non-profit organizations. With over 800 thousand employees and more than $\$ 238$ billion in industry shipments, the industry needs to focus on efficiency strategies in order to remain competitive.

In a report developed by Nyboer and Bennett (2013), biomass represents $54.4 \%$ of the total energy used in the Canadian wood products manufacturing industry

\footnotetext{
${ }^{1}$ Note that NAICS subsector 337 includes both wood and nonwood cabinets and furniture with the wood share comprising approximately $60 \%$ of the value of 2013 shipments (U.S. Census Bureau 2013).
}

(NAICS 321). After biomass, electricity represents $25.6 \%$, and natural gas $14.2 \%$ of total energy use. The same report indicated that the use of biomass and electricity continues to rise over time while energy from fossil fuels continues to decline. Similarly, the US Environmental Protection Agency (EPA 2007) reported that more than half of the US wood products industry's energy demands are met by using byproducts (waste biomass), which distinguishes the forest products industry from other manufacturing sectors.

As new technologies for boiler, kiln drying, and combined and heat power (CHP) systems based on biomass continue to be introduced, the industry needs to turn its attention to continuous improvement strategies to reduce and minimize electricity consumption as it represents $25 \%$ of the total energy use in the industry. A first step towards gaining knowledge on which strategies and industry segments might benefit the most from a focused energy improvement initiative is to understand the historical consumption of electricity in the wood products sector. Therefore, this article has as objectives to understand historical electrical consumption in the wood products industry and to compare consumption by industry type and US regions.

Electrical consumption data was extracted from the Industrial Assessment Center (IAC 2015) database using data mining procedures. This database allows data access based either on the NAICS code system or the previously used Industrial Classification System (SIC). The SIC system is still familiar to most readers and was the only code used to categorize operations before 2002 in the IAC dataset. In order to carry out an investigation of electrical consumption and energy recommendations for a 20 -year period, the SIC categories were employed here. The electrical consumption data was compared by industry type, year, and region. This comparison procedure required the development of standard electricity consumption metrics to compare across the factors. Acceptable metrics for these comparisons that reflect output and asset utilization efficiencies are as follows: consumption by employee, sales, and square footage or plant area. Hence, the following hypothesis was tested using the proper statistical procedures:

- $\mathrm{H}_{01}$ : There is no difference between energy consumption by employee, sales, and plant area based on the factors industry type, year, and US region. 


\section{Literature review}

Most of peer-reviewed papers based on the Industrial Assessment Center (IAC) database have focused on energy recommendations and their paybacks (Tonn and Martin 2000; Heymann 2005; Alhourani and Saxena 2009; Abadie et al. 2012; and Qiu et al. 2015) without conducting an analysis based on demographics such as plant area, sales, or number of employees. A distinctive study by Beyene and Moman (2006) based on the IAC database did study energy use based on SIC groups that show deviations within each group supporting the idea that code grouping is not very useful for further analysis and interpretation. To overcome this problem, the authors introduced a process oriented energy intensity classification (POEIC) to better examine the data.

There have been a few studies on energy efficiencies and wood products industries. For example, Dunning and Ward (1998) discussed the initial impacts of the IAC on the paper and the wood products industry. The authors discussed the various recommendations that were made through these assessments to industries, including the most common energy conservation opportunities and waste minimization opportunities. In 2006, Meil et al. published their work on understanding the consumption of energy in the Canadian wood products sector. The main goal of this study was to develop benchmark metrics and data for this industry based on surveys of selected sawmills. The study indicated that electricity and natural gas each account for about $20 \%$ of the industry's fuel mix. Also, Gopalakrishnan et al. (2012) conducted a benchmarking study of electricity consumption at sawmills. The study was based on the application of an interactive comparative model that collected information on product, process, and system parameters. The model was applied to six sawmills plants in West Virginia.

A few studies on energy and the wood products industry have been targeted the development of critical performance metrics for energy consumption. Gopalakrishnan et al. (2005) examined the energy utilization profile of the wood manufacturing industry by using certain production parameters such as $\mathrm{kWh}$ per thousand board feet (MBF) and dollars per $\mathrm{kWh}$. It was found out that the average cost ranged from $\$ 0.0482$ / $\mathrm{kWh}$ to $\$ 0.0791 / \mathrm{kWh}$. This research was conducted as one of the IAC projects located at the West Virginia University. The study concluded that there were a total of six recommended energy efficiency measures (EEM) based on the average payback period that could be implemented to reduced cost and increase energy efficiencies. Similarly, Lin et al. (2012) conducted another study on the consumption and efficiency of energy in hardwood sawmills located in the Appalachian region through a survey and an audit of 15 sawmills. Results of this work indicated that monthly electricity consumption per mill average $220 \mathrm{kWh}$ per thousand board feet (MBF) with an average electric monthly bill of $\$ 17.78 / \mathrm{MBF}$. The study also found out that in average, each mill releases about $587,045 \mathrm{lbs}$ of carbon dioxide per year related to electricity consumption. Finally, Devaru et al. (2014) investigated motor-based energy consumption in West Virginia sawmills. The goal in this research was to develop energy consumption profiles for the manufacturing of hardwood lumber in the Appalachian region. It was found out that energy consumption ranged from 84 to $111 \mathrm{kWh} /$ MBF. The data was based on a case study methodology by visiting three sawmills in the state of West Virginia.

Other studies on energy use in the wood products sector have focused more on how energy costs impact competitiveness of the industry. For example, Buehlmann et al. (2007) surveyed in 2005 hardwood sawmills located in the Appalachian region about perceived impacts of globalization. In addition to globalization issues, hardwood sawmill managers faced concerns in other issues such as energy and transportation costs (Espinoza et al. 2011a). Two fifths of the energy used by the US wood products comes from electricity and natural gas. The cost has been increasing. Survey was conducted to understand the impact of energy prices on profitability and to gain insights regarding actions that the industry is taking to respond to energy-related challenges. Half of survey respondents reported a $5 \%$ or higher negative impact of higher energy on their profits.

Overall, energy use studies on the wood products industry have focused on analyzing energy recommendations based on payback periods, developing performance metrics (based mostly on raw material), and in perceptions of the industry on energy use impacts. It was found that results on similar metrics are different and greatly vary even within the same industry type. Also, there has not been a comparison based on type (SIC grouping), size (plant size and number and employees), and sales that use data in the IAC database. 


\section{Methods}

Data mining and data selection

Data was acquired from the IAC energy best practices database (CAES 2014). The entire database was downloaded as an MS Excel file. Every assessment in the database is classified under a four-digit SIC. A dynamic table (also known as pivot table) was created to extract the meaningful data. The extracted data fields are as follows: assessment number, SIC, year, sales (\$), plant area $\left(\mathrm{ft}^{2}\right)$, electricity usage $(\mathrm{KWh})$, number of employees, and state.

The original extracted dataset contained 915 assessments conducted from 1994 to 2014 and classified under SIC codes 24 (sawmills, veneer, plywood, structural wood, miscellaneous wood products) and 25 (furniture and fixtures). The extracted dataset was revised to include only four-digit SIC assessments with more than 30 observations and only wood products industries. A summary of the revised dataset is shown in Table 1.

Figure 1 shows the distributions of the response variables of interest for the 610 records included in this preliminary sample.

Next, the data was inspected for anomalies and outliers. Anomalies consisted of empty cells or missing data, and outliers were defined as all data points outside the quantile range $0.5-99.5 \%$. After performing this data verification procedure, the sample size was reduced from $n=610$ to $n=529$. Figure 2 shows the new distribution of the data after the elimination of anomalies and outliers.

Finally, given that the data is clearly skewed to the left (see Fig. 2), normality and distribution symmetry could be an issue when performing further statistical analyses. To avoid potential issues, a logarithmic transformation was applied to the three response variables in order to increase the symmetry of the data distribution. The distributions of the transformed variables are presented in Fig. 3. A chi-square goodness-of-fit test was conducted to test for the normality of the log-transformed data, but in all cases, the null hypothesis that the transformed data is normal was rejected. However, given that the sample size is large enough $(n=529)$ and the non-normality is caused by skewness, the potential F-test to be conducted are robust to non-normality (French et al. 2008).

One of the potential limitations of this study is the sample selection which cannot be considered probabilistic as it is unknown how companies decided to participate in the IAC assessments. Therefore, the sampling method must be considered a convenience sample, which is a non-probabilistic sampling technique. Consequently, it may not be appropriate to make inferences about the population based on the sample. However, the number of companies that have been assessed in the IAC database (more than 15,000 to date of which 1267 were in SICs 24 and 25) seems to be a good indicator that knowledge of and access to this IAC service is broad; thus, the data in the database might be a reasonable representation of the total population.

Data analysis

The statistical software JMP from SAS was chosen to conduct the statistical analysis. Contingency tables were used to analyze the proportions of the data by year, region, and state. Chi-square and Fisher tests were used,
Table 1 Description of dataset which includes only those wood products industry sectors from SIC groups for which more than 30 assessments have been conducted

\begin{tabular}{llll}
\hline SIC & SIC descriptions & Sample size & Percent \\
\hline 2421 & Sawmills and planing mills, general & 150 & $24.6 \%$ \\
2431 & Millwork & 103 & $16.9 \%$ \\
2499 & Wood products, not elsewhere classified & 59 & $9.7 \%$ \\
2511 & Wood household furniture, except upholstered & 55 & $9.0 \%$ \\
2512 & Wood household furniture, upholstered & 42 & $6.9 \%$ \\
2493 & Reconstituted wood products & 38 & $6.2 \%$ \\
2434 & Wood kitchen cabinets & 35 & $5.7 \%$ \\
2426 & Hardwood dimension and flooring mills & 34 & $5.6 \%$ \\
2521 & Wood office furniture & 33 & $5.4 \%$ \\
2491 & Wood preserving & 31 & $5.1 \%$ \\
2451 & Mobile homes & 30 & $4.9 \%$ \\
& Total & 610 & $100.0 \%$ \\
\hline
\end{tabular}



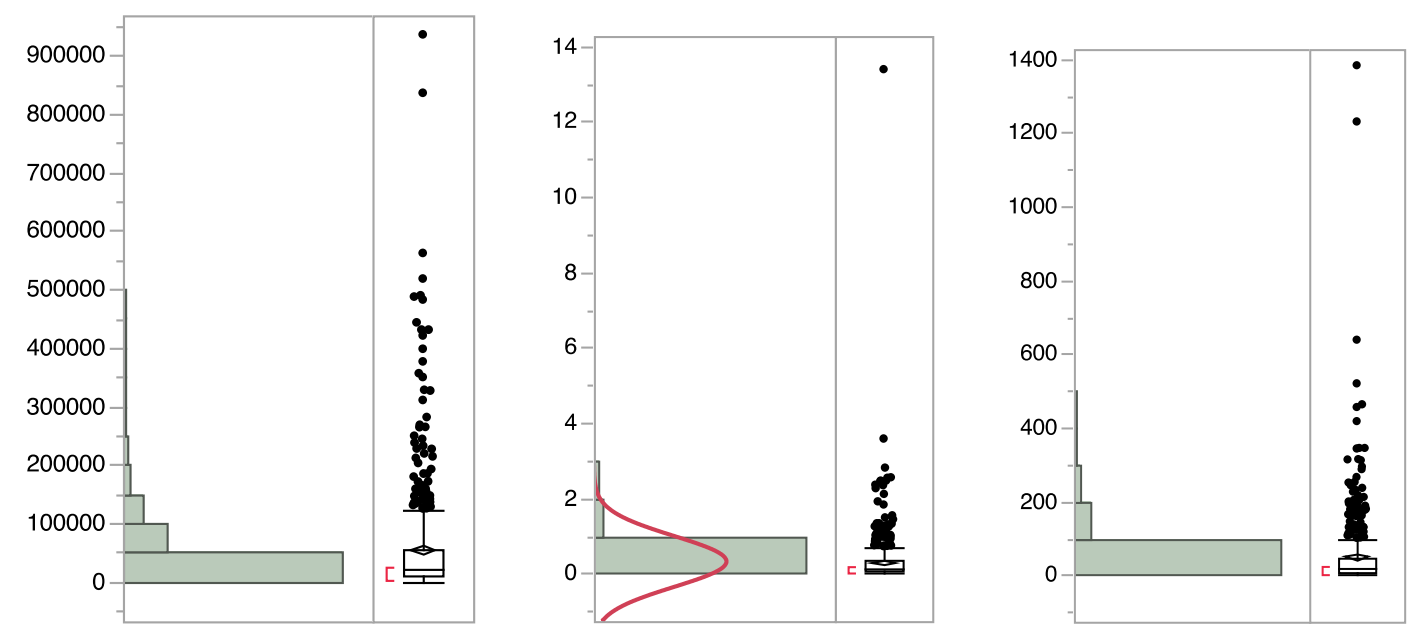

Fig. 1 Distribution of response variables electricity consumption by employee (KW/Employee), sales $(\mathrm{KWH} / \$)$, and plant area $\left(\mathrm{KWH} / \mathrm{ft}^{2}\right)$

as appropriate, to compare proportions by groups. The regions were defined using the definition by US Forest Service as shown in Table 2.

To test the hypothesis, factorial multivariate analysis of variance (MANOVA) was used. In this case, there are three continuous response variables $(\mathrm{kWh} / \mathrm{employee}$, $\mathrm{kWh} / \mathrm{sales}$, and $\mathrm{kWh} /$ plant area) and three independent, categorical variables (SIC, region, and year). The MANOVA approach increases the chance of finding a group difference when measuring several dependent variables (Lehman et al. 2013). Also, performing individual ANOVA tests increases the chance for type 1 error. However, the correlation among the dependent variables needs to be measured in order to verify that correlations are not strong to increase the power of the test. If the MANOVA test (Wilks' lambda) is significant, individual ANOVA tests are conducted in the independent variables to determine which one of the levels on each factor is significant.

\section{Results}

The following data analysis was conducted using the transformed data, but the reported means in the discussion section correspond to the original values. As recommended by Howell (2007), the researcher might choose to present the data using the original or the
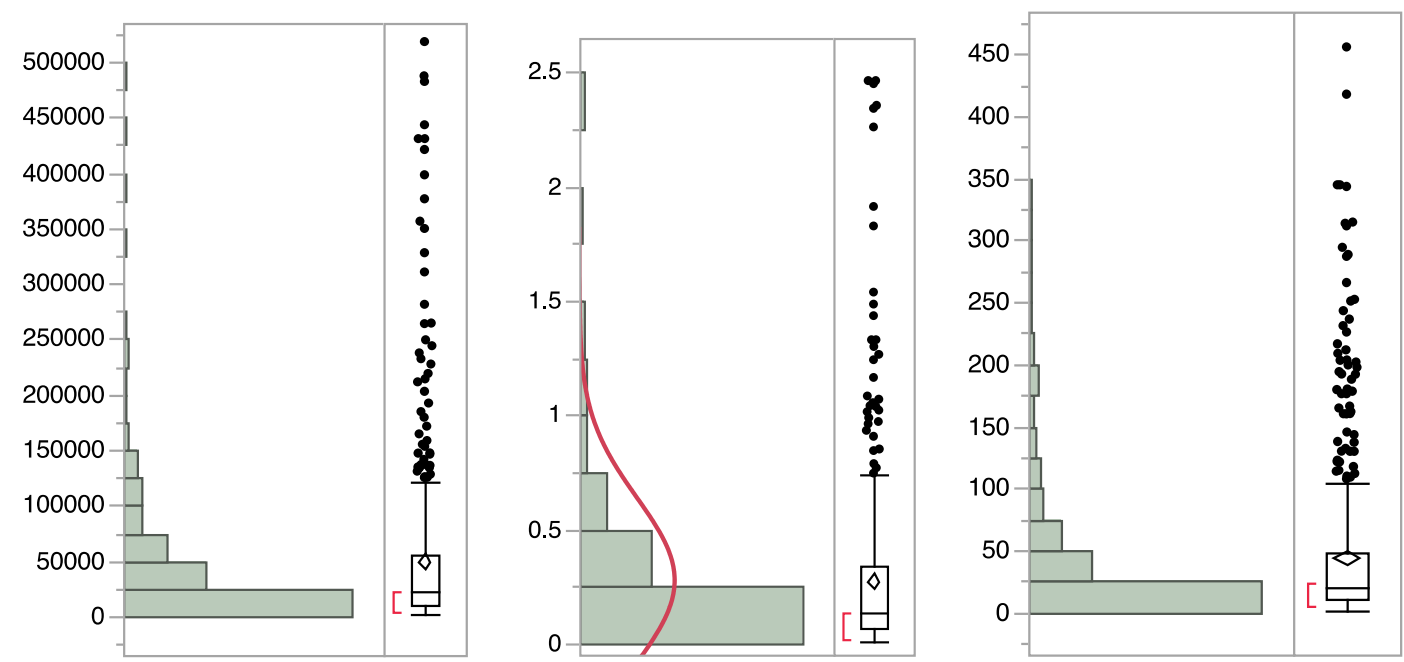

Fig. 2 Distribution of response variables consumption by employee, sales, and plant area after the elimination of anomalies and outliers outside the quantile range $0.5-99.5 \%$ 

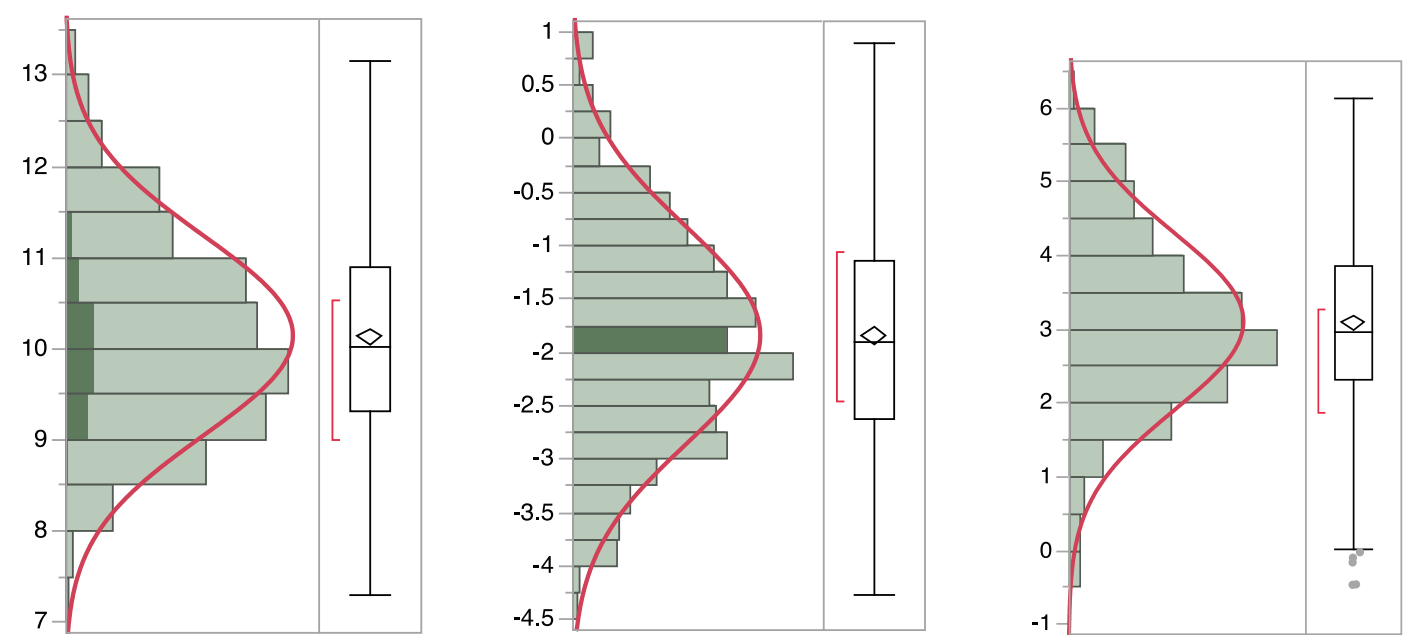

Fig. 3 Transformed data using a logarithm transformation. Left to right: $\log \mathrm{KWh} / \mathrm{employee,} \log \mathrm{KWh} / \mathrm{sales}$, and log KWh/plant area

transformed data. In this particular case, the backtransformations are not always straight forward; therefore, the original means are used in the discussion. In addition, the back-transformed means are called geometric means, and they are different than the arithmetic means from the original data. The only central tendency measure that remains the same for the original and the transformed data is the median

Contingency analysis by factors

As shown in Table 3, the majority of assessments have been performed on companies under SIC 2421(sawmills and planning mills) with 126 assessments from 1994 to 2014. The smallest sample size corresponds to SIC 2521

Table 2 Forest service regions (USDA forest service 2015)

\begin{tabular}{ll}
\hline Region & States included \\
\hline $\begin{array}{l}\text { Alaska } \\
\text { Eastern }\end{array}$ & AK \\
& $\begin{array}{c}\text { ME, VT, NH, MA, CT, RI, NJ, NY, DE, } \\
\text { MD, WV, PA, OH, IN, IL, MO, IA, } \\
\text { WI, MN, MI, OH }\end{array}$ \\
Intermountain & NV, UT, ID \\
Northern & MT, ND \\
Pacific Northwest & WA, OR \\
Pacific Southwest & CA, HI \\
Rocky Mountain & WY, CO, SD, NE, KS \\
Southern & DC, VA, KY, NC, TN, SC, GA, FL, Al, \\
& MS, AR, OK, TX, LA \\
Southwestern & AZ, NM \\
\hline
\end{tabular}

(wood office furniture) with only 26 assessments. Based on the mean consumption, SIC 2493 (reconstituted wood products; $n=31$ ) seems to be the industry sector with the highest energy consumption in all response variables. The mean consumption in this industry sector by employee, sales, and plant area are $238,096.28 \mathrm{kWh} /$ employee, $0.86 \mathrm{kWh} / \mathrm{sales}$, and $154.14 \mathrm{kWh} /$ plant area, respectively. The industry sector with the smallest reported electricity consumption in all the response variables is SIC $2451(n=29)$ with $6811.01 \mathrm{kWh} /$ employee, $0.05 \mathrm{kWh} / \mathrm{sales}$, and $9.45 \mathrm{kWH} /$ plant area.

When the data was grouped by region (Table 4), it was found that the East had the most assessments with a total of 152. The North and Alaska regions had one and zero assessments, respectively; therefore, they were dropped from analysis due to insufficient sample size. To consider the proportion of assessments by industry type and US region, a Likelihood ratio test was used to test for equivalent proportions among each cell. The results of this test (chi-square $=172.8$, $p<0.001)$ indicate that the proportional representation of different industry types among regions is different (significance level 0.05). For example, it is more likely that companies with SIC 2421 will participate in an assessment in the Pacific Northwest region than other industries in that region.

When looking at the number of assessments conducted by year, it can be seen in Table 5 that the highest number of assessments were conducted in year 2000 with 51, and the fewest assessments were conducted in 2010 with only 11 assessments. Again, a likelihood ratio test was conducted to test the 
Table 3 Electricity consumption means by SIC

\begin{tabular}{llllll}
\hline Industry type & SIC description & Sample size $(n)$ & KWh/ employee & KWh/ sales & KWh/ plant area \\
\hline 2421 & Sawmills and planing mills, general & 126 & $74,843.67$ & 0.38 & 65.51 \\
2426 & Hardwood dimension and flooring mills & 30 & $35,077.72$ & 0.27 & 52.30 \\
2431 & Millwork & 88 & $27,255.60$ & 0.19 & 27.57 \\
2434 & Wood kitchen cabinets & 31 & $14,763.84$ & 0.20 & 19.35 \\
2451 & Mobile homes & 29 & 6811.01 & 0.05 & 9.45 \\
2491 & Wood preserving & 30 & $43,412.90$ & 0.15 & 43.42 \\
2493 & Reconstituted wood products & 31 & $238,096.28$ & 0.86 & 154.14 \\
2499 & Wood products, not elsewhere classified & 49 & $52,541.33$ & 0.39 & 54.36 \\
2511 & Wood household furniture, except upholstered & 50 & $20,218.72$ & 0.20 & 25.17 \\
2512 & Wood household furniture, upholstered & 39 & $12,461.17$ & 0.09 & 10.15 \\
2521 & Wood office furniture & 26 & $13,086.27$ & 0.11 & 13.50 \\
\hline
\end{tabular}

proportion of assessments by year and by industry type. The results of this test indicated that the proportions are different (chi-square 275.3 and $p=0.003$, significance level of 0.05 ), indicating a potential relationship between industry type and the year the assessment was conducted.

\section{Hypothesis testing}

Figure 4 shows the mean log-transformed electricity consumption per employee, sales, and plant area. In all cases, the timeframe is 1994 to 2014. Figure 4a suggests that the consumption of each response variable is very similar from 1994 to 2014. When the response variables are grouped by industry type (Fig. 4b), it appears that there are some differences between industry groups for all response variables. In the regional grouping (Fig. 4c), the visual analysis indicates that there might be some differences among the response variables.

An important part of the analysis is to assess the correlations among the variables. If there are significant correlations, this could be an indication that there is a strong relationship between the predictor variables (industry type, year, and region) and the multiple response variables (transformed consumption by employment, sales, and plant area). In MANOVA, it is important to determine whether there is a relationship between the predictor variables and the response variables taken as group. Also of interest, strong associations between dependent variables might be an indication that two or more dependent variables could be measuring the same aspect (i.e., they are redundant). Table 6 shows the correlations between response variable pairs. These results indicate that there are moderate correlations between the dependent variables; therefore, a factorial MANOVA test should be more appropriate in this case than univariate ANOVA tests to accurately detect if there are significant relationships between the response variables and the predictors or factors.

The null hypothesis was tested using a factorial MANOVA between-subjects design. This analysis revealed significant multivariate effects for year, industry type, and region (Wilks' lambda $=0.2822$, $F(104,1441.4)=7.02 ; p<0.0001)$. The estimated
Table 4 Electricity consumption means by region

\begin{tabular}{lllll}
\hline Region & Sample size $(n)$ & KWh/employee & KWh/sales & KWh/plant area \\
\hline East & 152 & $47,012.65$ & 0.30 & 52.87 \\
Intermountain & 18 & $89,407.73$ & 0.41 & 46.76 \\
Pacific Northwest & 52 & $90,328.12$ & 0.39 & 62.37 \\
Pacific Southwest & 28 & $30,667.39$ & 0.17 & 26.29 \\
Rocky Mountain & 26 & $23,969.73$ & 0.17 & 36.90 \\
South & 235 & $47,413.24$ & 0.25 & 41.64 \\
Southwest & 18 & $30,836.06$ & 0.34 & 21.80 \\
\hline
\end{tabular}


Table 5 Electricity consumption means by year

Year Sample $\mathrm{KWh} /$ employee $\mathrm{KWh} /$ sales $\mathrm{KWh} /$ plant area size $(n)$

\begin{tabular}{lllll}
\hline 1994 & 29 & $24,397.00$ & 0.22 & 32.79 \\
1995 & 29 & $30,695.83$ & 0.20 & 45.48 \\
1996 & 35 & $39,274.92$ & 0.31 & 49.21 \\
1997 & 31 & $27,543.50$ & 0.24 & 34.96 \\
1998 & 27 & $32,022.10$ & 0.27 & 29.41 \\
1999 & 35 & $32,763.91$ & 0.22 & 32.24 \\
2000 & 51 & $47,802.68$ & 0.28 & 50.67 \\
2001 & 28 & $87,466.15$ & 0.33 & 61.11 \\
2002 & 27 & $42,762.29$ & 0.24 & 40.25 \\
2003 & 27 & $58,603.78$ & 0.37 & 39.51 \\
2004 & 25 & $53,456.79$ & 0.21 & 37.29 \\
2005 & 24 & $54,749.33$ & 0.23 & 56.87 \\
2006 & 12 & $38,641.58$ & 0.16 & 28.47 \\
2007 & 18 & $55,996.28$ & 0.29 & 53.21 \\
2008 & 12 & $60,267.53$ & 0.66 & 68.49 \\
2009 & 15 & $86,761.78$ & 0.25 & 55.49 \\
2010 & 11 & $108,216.20$ & 0.45 & 62.03 \\
2011 & 27 & $74,838.30$ & 0.35 & 56.63 \\
2012 & 19 & $50,515.65$ & 0.20 & 56.73 \\
2013 & 25 & $61,303.24$ & 0.23 & 43.68 \\
2014 & 22 & $59,997.88$ & 0.35 & 39.81 \\
\hline
\end{tabular}

parameters for the whole model and the factors are shown in Table 7. Given that the MANOVA test indicated that there is a multivariate effect expressed by the combination of independent variables (factors), a univariate ANOVA and Tukey's HSD tests were conducted for each individual response. These tests determine what levels of the factors are different from each other.

Table 8 displays the results of the univariate ANOVA and Tukey's HSD tests. This subsequent testing shows that there are some differences among the different levels of the factors in the analysis. The factor's levels (industry type, year, and region) that are listed separately in the row "Tukey's HSD differences" in Table 8 are considered different. For the case of the response variable $\log \mathrm{kWh} / \mathrm{employee}$, significant differences were found for all factors in the analysis. The factor industry type shows significant difference for all levels. The factor year has 8 Tukey HSD groups defined with one group quite large and the other seven groups containing only 1 or 2 years. When looking at differences for the factor region, it was found that there are differences among most of the regions as shown in Table 8.
When analyzing differences in the response variable $\log \mathrm{kWh} / \mathrm{sales}$, differences were found in for the factors industry type and region. Factor year did not show a significant difference between its levels. The differences in the levels of factor industry type were very similar to the ones found with response variable log kWh/employee. Regarding the factor region's groupings for $\mathrm{kWh} /$ sales, similar results were obtained to those for $\mathrm{kWh} /$ employee, but the order of the levels changed. In the case of the response variable $\log \mathrm{kWh} / \mathrm{plant}$ area, only the factor industry type produced significant differences (Table 8).

\section{Discussion}

As electricity consumption is on the rise, manufacturing industries such as wood products firms need to be strategic to mitigate the impacts of energy costs. The most important source of energy in wood products manufacturing firms is biomass, accounting for over $50 \%$ of the total energy required (EPA 2007; Nyboer and Bennett 2013). This is a unique feature of wood products industries that no other industry possesses. Most of the companies in this industry have taken advantage of their biomass waste, and it is used as a source of energy for their boilers or combined heat and power systems. In fact, biomass residues were a huge problem for the industry until recently; but now, not only are woody residues used as a source of energy but also biomass waste has found a market in the solid bioenergy industry (cogeneration and wood pellets; Bowyer et al. 2012). This new market has become an important revenue source for wood products industries.

The second most important source of energy after biomass waste in the wood products industry is electricity, which represents $25 \%$ of the total energy process and non-process energy consumption (Nyboer and Bennett 2013). Considering that the wood products subsector is a leader in the use of biomass waste as a source of energy, the next challenge for the industry is to develop strategies to increase efficiencies in electricity consumption.

\section{Electricity consumption by number of employees}

The response variable electricity consumption by number of employees ( $\mathrm{kWh} / \mathrm{employee}$ ) is an important measure of efficiency. Organizations today tend to be 

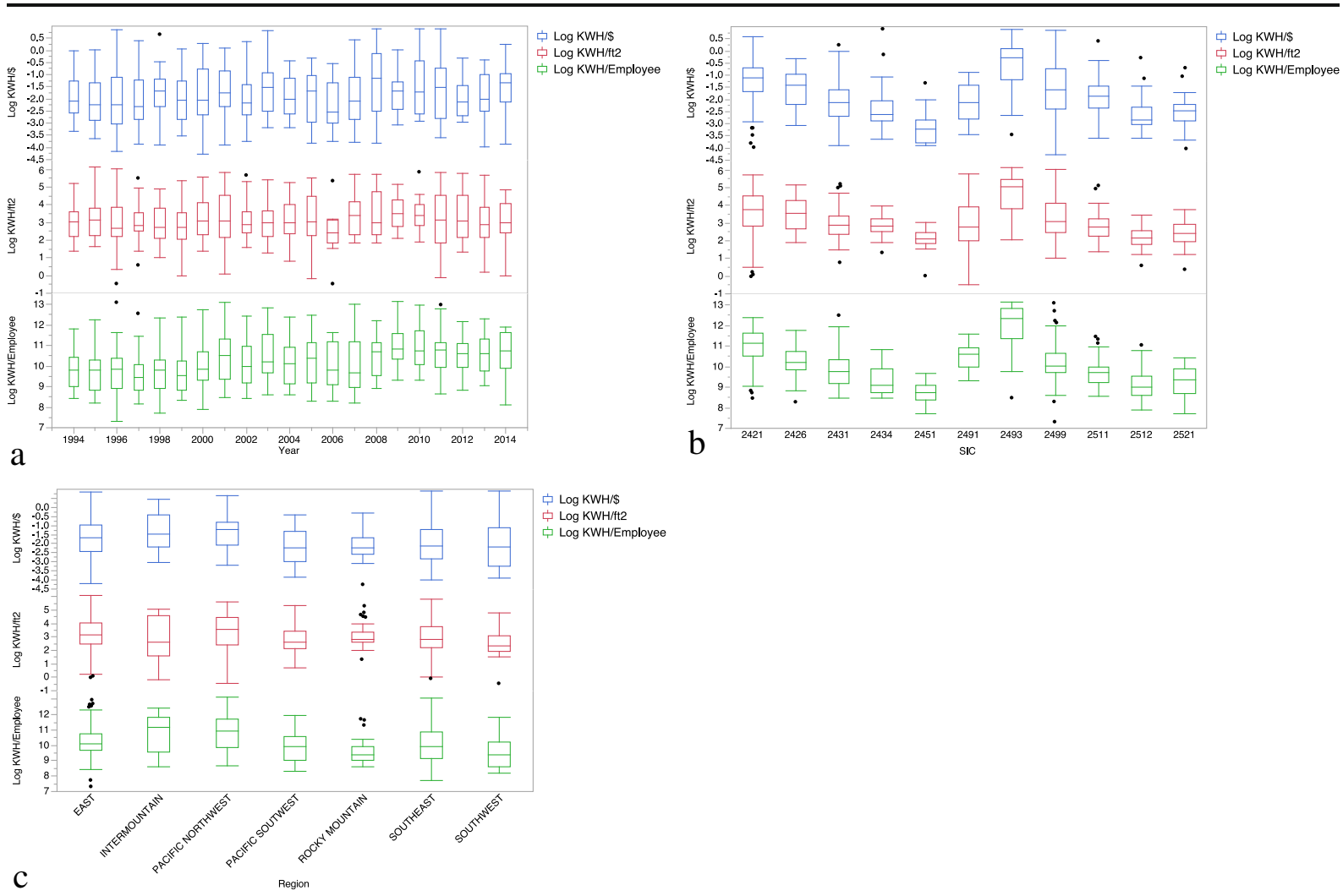

Fig. 4 Mean electricity consumption per employee (log KWh/employee), sales (log KWh/\$), and plant area $\left(\log \mathrm{KWh} / \mathrm{ft}^{2}\right)$ grouped by a year, $\mathbf{b}$ industry type, and $\mathbf{c}$ US region

smaller and more productive. Asset utilization becomes an important part of the efficiencies, and if employees are considered as the most important asset of any organization, then measuring electricity usage by employee is an important metric to be considered. Even though some industry sectors might be more labor intensive than others (for example, primary vs secondary industry), this metric still can be used as a benchmark.

For this response variable, there were differences for all three factors (industry code, year, and region). Reconstituted wood products (SIC 2493), the industry with by far the highest electricity consumption per employee, includes the manufacturing of products such as

Table 6 Correlations between response variables

\begin{tabular}{llll}
\hline & $\begin{array}{l}\text { Log kWh/ } \\
\text { employee }\end{array}$ & Log kWh/\$ & Log kWh/ $\mathrm{ft}^{2}$ \\
\hline $\log \mathrm{kWh} /$ Employee & - & 0.7592 & 0.6373 \\
$\log \mathrm{kWh} / \$$ & - & - & 0.5788 \\
$\log \mathrm{kWh} / \mathrm{ft}^{2}$ & - & - & - \\
\hline
\end{tabular}

hardboard, particleboard, insulation board, medium density fiberboard, wafer-board, and oriented strand board that require energy intensive process steps including material pressing and drying. SIC 2493 operations also tend to be fairly automated operations with fewer employees.

Reconstituted wood products consume over three times the amount of electricity per employee compared to the second highest consuming industry, SIC 2421 (Sawmills and Planing Mills). Sawmills and Planing Mills include primary processing operations with large

Table 7 Results of Wilk's lambda test

\begin{tabular}{lllll}
\hline Test parameters & Whole model & Year & Industry type & Region \\
\hline Value & 0.28 & 0.77 & 0.43 & 0.90 \\
Approx. F & 7.02 & 2.18 & 15.78 & 2.84 \\
NumDF & 104 & 60 & 30 & 18 \\
DenDF & 1441.4 & 1435.9 & 1412.5 & 1361 \\
Prob $>$ F & $<0.0001$ & $<0.0001$ & $<0.0001$ & $<0.001$ \\
\hline
\end{tabular}


Table 8 Univariate ANOVA and Tukey's HSD tests for each individual response ordered from highest to lowest on each response variable

\begin{tabular}{|c|c|c|c|c|}
\hline \multirow[t]{2}{*}{ Response variable } & \multirow[t]{2}{*}{ Test } & \multicolumn{3}{|l|}{ Factors } \\
\hline & & Industry type & Year & Region \\
\hline \multirow[t]{2}{*}{ Log kWh/employee } & ANOVA, $R^{2=} 0.53$ & $\mathrm{~F}(10,59.74), p<0.0001$ & $\mathrm{~F}(20,53.58), p<0.0001$ & $\mathrm{~F}(6,3.56), p<0.0018$ \\
\hline & Tukey's HSD differences & $\begin{array}{l}\cdot 2493 \\
\cdot 2421 \\
\cdot 2491 \\
\cdot 2499 \\
\cdot 2426 \\
\cdot 2431 \\
\cdot 2511 \\
\cdot 2434 \\
\cdot 2521 \\
\cdot 2512 \\
\cdot 2451\end{array}$ & $\begin{aligned} \cdot & 2010 \\
\cdot & 2009 \\
\cdot & 2012,2014,2011,2001, \\
& 2008,2013,2003,2004, \\
& 2005,2000,2002,1997 \\
\cdot & 1994,1995 \\
\cdot & 2006 \\
\cdot & 1999,1996 \\
\cdot & 2007 \\
\cdot & 1998\end{aligned}$ & $\begin{array}{l}\text { - Pacific Northwest } \\
\text { - Intermountain, East, South } \\
\text { - Pacific Southwest } \\
\text { - Southwest } \\
\text { - Rocky Mountain }\end{array}$ \\
\hline \multirow[t]{2}{*}{ Log $\mathrm{kWh} / \mathrm{sales}$} & ANOVA, $R^{2}=0.39$ & $\mathrm{~F}(10,23.60), p<0.0001$ & $\mathrm{~F}(20,0.99), p=0.48$ & $\mathrm{~F}(6,3.14), p=0.0049$ \\
\hline & Tukey's HSD differences & $\begin{array}{l}\cdot 2493 \\
\cdot 2421 \\
\cdot 2426,2499 \\
\cdot 2511 \\
\cdot 2431,2491 \\
\cdot 2434 \\
\cdot 2521 \\
\cdot 2512 \\
\cdot 2451\end{array}$ & No significant differences & $\begin{array}{l}\text { - Pacific Northwest } \\
\text { - Intermountain, East, Southwest } \\
\text { - South } \\
\text { - Rocky mountain } \\
\text { - Pacific southwest }\end{array}$ \\
\hline \multirow[t]{2}{*}{ Log $\mathrm{kWh} /$ plant area } & ANOVA, $R^{2}=0.29$ & $\mathrm{~F}(10,16.88), p<0.0001$ & $\mathrm{~F}(20,0.96), p=0.50$ & $\mathrm{~F}(6,1.66), p=0.13$ \\
\hline & Tukey's HSD differences & $\begin{array}{l}\cdot 2493 \\
\cdot 2421 \\
\cdot 2426,2499 \\
\cdot 2431 \\
\cdot 2511 \\
\cdot 2434,2491, \\
\cdot 2521 \\
\cdot 2451 \\
\cdot 2512\end{array}$ & No significant differences & No significant differences \\
\hline
\end{tabular}

electrical demands on motors that saw logs and cants and chip roundwood sections. Also, lumber dry kilns are included in this industry group. SIC 2421 has $1.4 \times$ the electrical consumption per employee as does the next industry on the list. These findings align with expectations for electricity consumption given the nature (high energy consumption processes) of these top two industry segments. By contrast, the mobile home manufacturing industry, which is mostly dedicated to assembly operations that are less consumptive, has minor energy consumption.

When the variable ( $\mathrm{kWh} / \mathrm{employees})$ was analyzed by year, it was found that there were differences among some of the years. The univariate ANOVA test showed the year with the highest consumption by employee was 2010 with 108,216.20 kWh/employee and the year with the lowest consumption was 1994 with $24,397.00 \mathrm{kWh} /$ employee. As years 2010 and 2009 were identified as the years with the highest consumption, a group of 12 years were found to have the same electricity consumption (see Table 8 ) for this response variable. There is no information that helps to explain why 2010 and 2009 show the highest consumption; however, it might be tied to the economic downturn that the manufacturing sector suffered from 2008 to 2011. For example, wood products manufacturers were laying off employees at a faster rate than they were slowing down production during the beginning of the recession. Of note, just before the downturn, which started in 2008, the levels of electricity consumption per employee for the years 2006 and 2007 were significantly lower. A possible explanation - housing starts and home sales and 
associated wood products (e.g., millwork, furniture) were booming during these 2 years; thus, manufacturing operations kept full payrolls to ensure they could respond quickly to meet customer demand.

Differences were also found for the factor region for the electricity consumption by employee variable. The region Pacific Northwest ( $n=52$ ) was found to have the highest electricity consumption by employee with 90,398.12 kWh/employee and region Rocky Mountain had the lowest with $23,969.73 \mathrm{kWh} /$ employee. As before, there is no data that definitively explains the differences by region. However, this could be tied to the number of industry types present in each region's dataset. A closer examination of the frequency distribution of the data by industry type (SIC) and region (see Table 9) revealed that $34.6 \%(n=18)$ of assessments in the Pacific Northwest corresponded to SIC 2421 (Sawmills and Planing Mills), $19.2 \%(n=10)$ to SIC 2431 (Millwork), and $15.4 \%(n=8)$ to SIC 2493 (Reconstituted Wood Products). Thus, in the region with the highest electricity consumption per employee, $50 \%$ of the assessments were performed in operations belonging to the two industry types with the highest energy consumption per employee.

The region where the largest number of SIC 2493 assessments were conducted was the South region $(n=12)$; however in the South, SIC 2493 assessments made up only $5 \%$ of all assessments. Given the proportional representation of different types of industries participating in the energy assessments in the different regions, a Likelihood test was conducted. Test results (chi-square $=172.8, p<0.001$, significance level of 0.05 ) showed that the proportion of industry types by regions is significant, indicating a relationship among these factors. Considering the Likelihood ratio test, it is more likely for assessments in the Pacific Northwest to come from industries with SIC 2421 (Sawmill and Planing Mills), the industry group with the second highest electricity consumption per employee.

\section{Electricity consumption by sales}

A different way to measure energy efficiencies is to consider industry consumption related to industry output. This ratio indicates how much electricity was required to produce each dollar that the company generated. Similar to consumption per employee, this ratio reflects a level of efficiency in electricity usage. The univariate ANOVA tests that were conducted to determine which factors were impacting the response variable consumption by sales $(\mathrm{kWh} / \mathrm{sales})$ indicated there were statistical significant differences among levels for the factors industry type (SIC) and region. No significance was found for the factor year (Table 8).

As with the response variable electricity consumption per employee, SIC 2493 (Reconstituted Wood Products) has the highest energy consumption by sales with $0.86 \mathrm{kWh} / \mathrm{sales}$ and the SIC with the smallest consumption by sales was SIC 2451 with $0.05 \mathrm{kWh} /$ sales. Overall, the industry level results are very similar for $\mathrm{kWh} / \mathrm{sales}$ to the results for $\mathrm{kWh} / \mathrm{employee}$. There were two groupings of SIC levels (2426 and 2499; 2431 and 2491) that showed no differences for consumption by sales.

Very similar to dependent variable consumption by employee, differences between the levels of factor region were found (Table 8). The Intermountain and Pacific Northwest region have the highest electricity consumption by sales with $0.41 \mathrm{KWh} /$ sales and 0.39 $\mathrm{KWh} / \mathrm{sales}$, respectively. And the regions Rocky Mountain and Pacific Southwest were identified as the regions with the smallest electricity consumption with

Table 9 Frequency distribution of assessments by industry type and region

\begin{tabular}{llllllllllll}
\hline Regions & 2421 & 2426 & 2431 & 2434 & 2451 & 2491 & 2493 & 2499 & 2511 & 2512 & 2521 \\
\hline East & 35 & 9 & 24 & 6 & 7 & 5 & 8 & 30 & 14 & 3 \\
Intermountain & 11 & 0 & 1 & 2 & 0 & 2 & 1 & 0 & 0 & 1 & 0 \\
Pacific Northwest & 18 & 1 & 10 & 3 & 5 & 3 & 8 & 1 & 3 & 0 & 0 \\
Pacific Southwest & 7 & 0 & 10 & 2 & 0 & 1 & 1 & 4 & 1 & 2 & 0 \\
Rocky Mountain & 4 & 1 & 11 & 7 & 0 & 1 & 0 & 1 & 1 & 0 & 0 \\
South & 50 & 19 & 27 & 8 & 15 & 17 & 12 & 11 & 29 & 33 & 14 \\
Southwest & 1 & 0 & 5 & 3 & 2 & 1 & 1 & 2 & 2 & 0 & 1 \\
Total & 126 & 30 & 88 & 31 & 29 & 30 & 31 & 49 & 50 & 39 & 26 \\
\hline
\end{tabular}


$0.17 \mathrm{kWH} / \$$ each. These results might be influenced by the fact that only one company with SIC 2493 (Reconstituted Wood Products) participated in the assessments in the Pacific Southwest region and none in the Rocky Mountain region (Table 9). Finally, for this particular response variable, no differences were found among the levels of the factor year.

\section{Electricity consumption by plant area}

This performance metric is similar to electricity consumption by employee ( $\mathrm{kWh} /$ employee) as they both are measures of efficiencies on asset utilization. Space utilization has become an important indicator of how efficient a company utilizes its capital asset. Space is expensive to build, maintain, or rent. In addition, administrative expenses such as electricity or insurance are directly proportional to the amount of building space a company needs and maintains.

After performing a univariate ANOVA test for variable consumption by plant area, it was found that out of the three factors, only industry type was significant. There were no significant differences in factors year and region (Table 8). The differences among the levels of factor industry type were almost identical to the ones found for dependent variable electricity consumption by sales. SIC 2493 is again the industry sector with the highest electricity consumption by plant area with $154.14 \mathrm{kWh} /$ plant area while SIC 2512 (Wood Household Furniture, Upholstered) and 2451 (Mobile Homes) are the industry sectors with the smallest consumption by plant area-about $6 \%$ the consumption per square foot of SIC 2493.

Final remarks

As it was pointed out in the discussion of the response variable electricity consumption by employee, a substantial opportunity exists for industries in SIC 2493 (Reconstituted Wood) to develop and implement specific strategies to gain electricity efficiencies in order to increase asset utilization (employees and plant area). Of the 137 unique recommendations that were produced in the IAC assessments performed for SIC 2493, 16 were offered 5 or more times. Of these, "utilize higher efficiency lamps and/or ballasts," "utilized energy-efficient belts and other improved mechanisms," and "eliminate leaks in inert gas and compressed air lines/valves" were the most common recommendations, having been cited more than 20 times each. Cited five times, "keep boiler tubes clean" was the commonly occurring recommendation offering the greatest average savings: $\$ 144,797$ per year. The payback period for implementation of this recommendation was estimated to be only 4.3 months.

An evaluation of nine hardwood sawmills by the IAC at West Virginia University (Gopalakrishnan et al. 2005) produced insights specific to this sector of the industry. Both compressor system and motor system-based energy efficiency recommendations were made for each of the nine sawmill operations studied, and the average payback period for these was cited as 2 months. For only one of the nine sawmill operations was a woodbased cogeneration recommendation made with a payback period of 43 months, but an energy efficiency savings that far exceeded savings associated with other recommendations. For this operation, underutilized boiler capacity and low-pressure steam requirements for the kiln operation indicated the cogeneration opportunity (Gopalakrishnan et al. 2005).

The participation level of wood products industry members in energy management activities in 2010 as reported in the Manufacturing Energy Consumption Survey Results (MECS) (EIA 2013) indicates a lower level of participation compared to overall results for all manufacturing sectors. Overall, $46.7 \%$ of responding manufacturing companies indicated participation in at least one type of energy management activity (e.g., energy audits, electricity load controls, equipment retrofits to change energy source). The participation rate in SIC 25 (furniture and related products) was only $35.1 \%$, and in SIC 24 (wood products, principally primary wood products), it was $44.9 \%$. These percentages are very similar to those reported by Espinoza et al. (2011b) for the hardwood industry in $2010(41.3 \%$ energy efficiency management participation rate).

There was also an indication from the analysis that the primary wood products industries (industries classified under SIC 24) consume more electricity than secondary wood products industries (SIC 25 classification). The main reason for this difference likely is due to the distinctive equipment configurations of the two groups of industries. Wood products composite industries such as plywood, medium, and hard density fiber (MDF and HDF) board, and oriented strand board (OSB) are usually classified under SIC 24, and they require higher electricity consuming equipment such has hot presses, larger boiler systems for kiln drying, and in general larger equipment than industries classified under SIC 
25. The Espinoza et al. (2011a) survey of hardwood manufacturers had a similar result with primary manufacturers (hardwood SIC 24 companies) indicating the average share of total costs attributable to energy expenses was $9.7 \%$ while secondary manufacturers reported an average energy cost share of $7.1 \%$. As observed by Meil et al. (2009) in considering energy use in different types of primary wood product manufacturing, there appears to be an indirect relationship between energy use and the size of the wood fiber in the produced product. Reconstituted products such as oriented strand board, particle board, and medium density fiberboard have higher process energy requirements than lumber and plywood (Meil et al. 2009).

\section{Summary and conclusions}

This paper examines the effect of the factors industry type, year, and region simultaneously on electricity consumption by employee, sales, and plant area for wood products industries. Data was extracted from the Industrial Assessment Center (IAC) database using data mining procedures in MS Excel spreadsheets. The extracted dataset was examined and procedures to exclude outliers as well as data transformations were applied to the original data. Correlation measurements indicated a moderate association between the response variables; therefore, a MANOVA test was performed to measure the impact of the factors industry type, year, and region on all response variables.

The results indicated the factors had an effect on all dependent variables. Subsequently, univariate ANOVA tests were conducted to find out what levels of the factors were different on each individual response variable. As expected, it was found that almost each level of the factor industry type was different as some of the industries are more energy intensive than others. Interestingly, differences in regional consumption were found. Examination of the region effect showed this could be linked to the proportion of regional assessments conducted in various types of industries. Differences in species processed in different regions also may affect energy consumption, but this effect cannot be examined using the IAC data. The data analysis also indicated differences in the levels of factor year but only for one response variable (electricity consumption by employee) while for the other response variables no differences were found.
The hope and expectation at the outset of this study was that we would see energy reductions over time reflected in the IAC data. This was not the case. Development of more energy-efficient systems and greater awareness of the costs of energy should lead to the adoption of the recommendations put forth in IAC audits. Repeating this study in 5 years will indicate if the progress in energy conservation that we had hoped to see here is finally being made. Opportunities to identify and act on energy efficiency strategies will be pursued when credit and cash flow are more readily available, as they should be with an economy that has largely recovered from a significant recession. However, incentives to pursue energy efficiency strategies may be weakened by the depressed oil and gas prices that prevail in 2015 .

The recommendations contained in the IAC database for different industry types need to be shared more broadly with wood industry managers - state extension personnel and industry associations can play a role in seeing that this happens. In sum, these recommendations provide intelligence on important cost saving opportunities.

Acknowledgments This work was funded through a cooperative agreement (13-JV-11242301-080) with the US Forest Service and The Department of Sustainable Biomaterials at Virginia Tech

\section{References}

Abadie, L. M., Ortiz, R. A., \& Galarraga, I. (2012). Determinants of energy efficiency investments in the US. Energy Policy, 45, 551-566.

Alhourani, F., \& Saxena, U. (2009). Factors affecting the implementation rates of energy and productivity recommendations in small and medium sized companies. Journal of Manufacturing Systems, 28(1), 41-45.

Beyene, A., \& Moman, A. (2006). Process oriented industrial classification based on energy intensity. Applied Thermal Engineering, 26(17/18), 2079-2086.

Bowyer, J., Bratkovich, S., and Fernholz, K. (2012). Utilization of harvested wood by the North American forest products industry. Report. Dovetail Partners, Inc. Minneapolis, MN. 23 pp. http://www.dovetailinc.org/report_pdfs/2012/ dovetailwoodutilization1012.pdf. Accessed 21 Oct 2014.

Buehlmann, U., Bumgardner, M., Schuler, A., \& Barford, M. (2007). Assessing the impacts of global competition on the Appalachian hardwood industry. Forest Product Journal, 57(3), 89-94.

Center for Advanced Energy Systems (CAES). (2014). Industrial assessment centers database. http://iac.rutgers.edu/database/. Accessed 11 Aug 2014. 
Devaru, D. G., Maddula, R., Grushecky, S. T., \& Gopalakrishnan, B. (2014). Motor-based energy consumption in West Virginia Sawmills. Forest Products Journal, 64(1/2), 33-40.

Dunning, S., and Ward, T. 1998. Energy and waste saving measures for the paper and wood products industry. Pulp and Paper Industry Technical Conference, Conference Record of 1998 Annual. IEEE. Pages 80-86. 21-26 June. Portland, ME.

Energy Information Administration (EIA). (2013). Manufacturing Energy Consumption Survey. https://www.eia.gov/ consumption/manufacturing/. Accessed 16 Dec 2015.

Energy Information Administration (EIA). (2014). Annual energy outlook 2014 early release overview. http://www.eia.gov/ forecasts/aeo/er/pdf/0383er(2014).pdf. Accessed 24 Mar 2015.

Energy Information Administration (EIA). (2014) Manufacturing energy consumption survey. (http://www.eia.gov/ consumption/manufacturing/data/2010/). Accessed 28 Jan 2015 .

Environmental Protection Agency (EPA). (2007). Energy trends in selected manufacturing sectors: opportunities and challenges for environmentally preferable energy outcomes. Office of Policy, Economics, and Innovation. http://www.epa.gov/ sectors/pdf/energy/ch3-5.pdf. Accessed 13 Jan 2015.

Espinoza, O., Bond, B. H., \& Buehlmann, U. (2011a). Energy and the U.S. hardwood industry - part 1: responses to increasing prices. Bioresources, 6(4), 3883-3898.

Espinoza, O., Bond, B. H., \& Buehlmann, U. (2011b). Energy and the U.S. hardwood industry - part 2: profile and impact of prices. Bioresources, 6(4), 3899-3914.

French, A., Macedo, M., Poulsen, J., Waterson, T., and Yu, A. (2008). Multivariate analysis of variance (MANOVA). San Francisco State University. http://userwww.sfsu.edu/efc/ classes/biol710/manova/manovanewest.htm. Accessed 9 Mar 2015.

Gopalakrishnan, B., Mate, A., Mardikar, Y., Gupta, D. P., Plummer, R. W., \& Anderson, B. (2005). Energy efficiency measures in the wood manufacturing industry. Proceedings of the 2005 ACEEE (American Council for an Energy Efficient Economy) Summer Study on Energy Efficiency in Industry on CD ROM, ISBN 0-918249-54-6, West Point, New York.

Gopalakrishnan, B., Mardikar, Y., Gupta, D., Mohammad Jalali, S., \& Chaudhari, S. (2012). Establishing baseline electrical energy consumption in wood processing sawmills for lean energy initiatives: a model based on energy analysis and diagnostics. Energy Engineering, 109(5), 40-80.

Heymann, D. (2005). Pacific Northwest efficient-energy initiatives. Environmental Quality Management, 15(2), 91-97.

Howell, D. C. (2007). Statistical methods for psychology. Belmont: Thomson Wadsworth.

Industrial Assessment Center (IAC). 2015. IAC Database. https:// iac.university/\#database. Accessed 11 Nov 2015.

Lehman, A., O'Rourke, N., Hatcher, L., \& Stepanski, E. (2013). JMP for basic univariate and multivariate statistics. Cary: SAS Institute Inc.

Lin, W., Wang, W., Shawn, G., David, S., and Gopalakrishnan, B. (2012). Energy consumption and efficiency of Appalachian Harwood Mills, Forest Products Journal, 62(1):32-38.

Meil, J., Bushi, L., Garrahan, P., Aston, R., Gingras, A., and Elustondo, D. (2009). Status of energy use in the Canadian wood products sector. Final Report for Project No. 6014. FPInnovations -Forintek, Vancouver, BC CANADA 53 p.

Nyboer, J., and Bennett, M. (2013). Energy use and related DATA: Canadian wood products industry 1990, 1995 to 2011. Canadian Industrial Energy End-use Data and Analysis Centre (CIEEDAC). http://www2.cieedac.sfu.ca/media/ publications/Wood_Products_Report 2012_(2011)_Final. pdf. Accessed 29 Jan 2015.

Pellegrino, J., Margolis, N., Justiniano, M., and Miller, M. (2004). Energy use, loss and opportunities analysis. Department of Energy. https://www1.eere.energy.gov/manufacturing/ intensiveprocesses/pdfs/energy_use_loss_opportunities analysis.pdf. Accessed 29 Jan 2015.

Qiu, Y., Wang, Y., \& Wang, J. (2015). Implied discount rate and payback threshold of energy efficiency investment in the industrial sector. Applied Economics, 47(21), 2218-2233.

Quesada-Pineda, H.J. and Buehlmann, U. (2011). Lean thinking: examples and applications in the wood products industry. Virginia Cooperative Extension (Peer-reviewed article 420 002) November, pp. 1-15.

Tonn, B., \& Martin, M. (2000). Industrial energy efficiency decision making. Energy Policy, 28, 12-831.

United States Census Bureau. (2013). Annual survey of manufacturers: value of products shipments: value of shipments for products classes, Table AM1331VS101; generated by Jan Wiedenbeck; using American < http://factfinder.census.gov/>. Accessed 04 Aug 2015.

United States Department of Agriculture (USDA) Forest Service. (2015). Forest service regions. http://www.fs.fed.us/ wildflowers/regions/. Accessed 30 Mar 2015. 